\title{
AGROCLIMATIC ZONING OF SEMIARID REGION OF ZACATECAS, MEXICO
}

\author{
BAutistA-CAPETILlo, C. - PACHECO-GUERRERO, A. - GONZÁlEZ-TRINIDAD, J. - \\ JÚNEZ-FERREIRA, $\mathrm{H}$.
}

\begin{abstract}
Doctorado en Ciencias de la Ingeniería, Universidad Autónoma de Zacatecas
Campus UAZ Siglo XXI, Zacatecas, Zacatecas, México

(e-mails: baucap@uaz.edu.mx; jgonza@uaz.edu.mx; hejunez@hotmail.com)
\end{abstract}

*Corresponding author

e-mail: anuard.pacheco@uaz.edu.mx

(Received 21 $1^{\text {st }}$ Aug 2017; accepted 21 ${ }^{\text {st }}$ Nov 2017)

\begin{abstract}
Agroclimatology concerns those climate processes influencing agricultural production, especially with respect to crops growing under rainfed conditions. A number of methodologies have been used to classify climate variables. The goal of this research was to obtain the agroclimatic delimitation for the Zacatecas region in Mexico using the Papadakis classification and collecting time-series data from 133 weather stations to obtain monthly thermal and monthly water parameters. The dataset is composed of information collected for the period of 1960-2015. For all weather stations data were filtered and chronologically sorted to complete any missing information using a geostatistical and Kalman filter approach. Monthly average values were interpolated using the ordinary Kriging method. Twelve maps were plotted to characterize agroclimatic conditions showing that January, February, November, and December are months that are too cool for agricultural practices. The climate conditions begin to become benevolent for agriculture from April. Three different agroclimatic zones were obtained for Zacatecas region. More than $90 \%$ of the surface is under the 2.2 climate type favoring crops such as maize, beans, and soybeans. Agroclimatic understanding is particularly important in semiarid regions because this permits proactive actions for promoting the agricultural potential of regions with scarce rainfall regimes.

Keywords: agroclimatology, Papadakis classification, semiarid region
\end{abstract}

\section{Introduction}

Climatology is the scientific study of regional weather patterns (Holden and Brereton, 2004). Assessment of variables such as precipitation, temperature, and evapotranspiration as well as the probability of occurrence of specific events along space and time is the most significant contribution of this branch of knowledge. In particular, agroclimatology concerns those climate processes influencing agricultural production (Holden and Brereton, 2004). Climate has been classified using methodologies such as Thornthwaite (1948), Köppen (1936), Köppen modified by García (García, 2004), Emberger (Di Castri and Hajek, 1976), and Papadakis (CamposAranda, 1999). Such alternatives are focused in the study of interactions temperature and humidity. Nevertheless, the Papadakis (1980) method takes into account climate aspects that influence both crops and water-soil-plant-atmosphere relations. This method allows evaluating the potential and limitations of crop growth in different climatic areas (Velasco and Pimentel, 2010).

Agroclimatic regions are characterized by interdependence between agronomy or farming systems and climate (Holden and Brereton, 2004; White et al., 2001). High climate variability in arid and semiarid lands makes farming a risky business; hence, the measuring and assessing of climate variability can be beneficial in determining the scheduling of agricultural activities for optimum production (Moeletsi and Walker, 
2013). Risks in agricultural production could be minimized, chiefly for rainfed agriculture, with an adequate geographical zoning of crops considering factors such as climatic conditions, soil characteristics, and availability of water, in order to ensure better conditions for the farming systems (Vidal and Martelo, 1993). The agroclimatic approach is used as a methodology to delimit a terrestrial space into several zones where the climate factors are favorable for certain groups of crops with similar characteristics (White et al., 2001).

Numerous studies on agroclimatic zoning have been undertaken. Falasca et al. (2012) plotted potential production areas of industrial oil and biodiesel from bean crop in arid and semiarid zones of Argentina by applying an agroclimatic model that combines precipitation, temperature and frost days. To estimate the agroclimatic potential in four places of the Bolivian Highlands, García et al. (2007) statistically analyzed more than 36 years of climatic data. Their main findings reveal that rainfed agriculture is risky due to the adverse climatic conditions, requiring the implementation of actions such as the introduction of deficit irrigation, protected intensive cropping, and cultivation of crops characterized by: (i) short growing season requirement, (ii) low water availability tolerance, and (iii) frost resistance. Previously, Geerts et al. (2006) conducted a study at the same Bolivian region to define areas with possibilities to improve quinoa production under deficit irrigation. Those authors evaluated four derived climatic indicators (reference evapotranspiration, length of rainy season, aridity index, and monthly frost risk) resulting in the agroclimatic quinoa GIS (geographic information system) map library. Morales et al. (2006) performed an evaluation and classification of edaphic and climatic resources in the Coquimbo Region of northern Chile using topoclimatic algorithms and satellite images, integrated in a GIS environment. Teran et al. (1998) executed the agroclimatic analysis of the La Mojana region in northern Colombia in order to estimate the potential for agriculture; using climate zoning, the theoretical estimate of potential crop areas and identification of consumption and excess of water in situ.

In Mexico, a number of studies report on agroclimatic patterns. Martinez et al. (2010) studied the agroclimatic conditions, chemical and nutritional characterization of kernels of Jatropha curcas L. (Mexican piñon), and they obtained the impact of different agroclimatic conditions in the composition of the seeds; Nuñez-Colín and Goytia-Jiménez (2009) determined the distribution and climatic patterns of current and future physic nut cultivation regions in Mexico using GIS; Diaz et al. (2000) performed agroclimatic zoning in the region of the highlands of Chiapas in southeastern Mexico, where they obtained maps of climatic suitability for cultivation of potato; Velasco and Pimentel (2010) applied the Papadakis methodology for agroclimatic delimitation to a wide region in Sinaloa in northwestern Mexico; they concluded by indicating that agroclimatic zonification can be very useful for planning purposes when different options of agricultural programs are applied; even when many crops are adapted to local conditions, it is important to know the natural climatic characteristics, so that the adaption process of crops is less hazardous if agricultural producers take into account regional climate to avoid wrong decisions as much as possible.

Zacatecas territory is depicted for corn and bean cultivars under rainfed conditions because of the local climatology. Nevertheless, yield for such crops generates low incomes for farmers whereby a part of agricultural producers use groundwater to cultivate higher income crops; furthermore, high rates of groundwater extraction originate environmental effects in Zacatecas aquifers. To contribute to the preservation of water resources, the goal of this research was to obtain the agroclimatic delimitation 
for the Zacatecas in Mexico, using the classification system of Papadakis (1980), collecting time-series data from 133 climatological stations in the region as monitored by the National Institute of Forestry, Agricultural and Livestock Research (INIFAP), and the National Water Commission (CONAGUA).

\section{Materials and methods}

\section{Location of study}

Zacatecas is located in the Northern region of Mexico, between extreme geographical coordinates $21^{\circ} 01^{\prime} 45.0^{\prime}$ ' $\mathrm{N}$ latitude and $100^{\circ} 43^{\prime} 34.3$ ' ' W longitude, and $25^{\circ} 07^{\prime} 21.5^{\prime}$ ' N latitude and $104^{\circ} 22$ ' 56.4' 'W longitude (Figure 1). The West and Southwest of the territory is part of the Sierra Madre Occidental mountain range conformed by plateaus reaching 2,850 $\mathrm{m}$ above sea level. The Central portion is set in the Meseta Central Highland, with valleys at around 1,000 $\mathrm{m}$ above sea level. The North is part of the Sierra Madre Oriental mountain range, with the highest elevations of the State, reaching an altitude of 3,200 $\mathrm{m}$ above sea level (INEGI, 2017). Zacatecas climate is semiarid, with minimum and maximum mean monthly temperatures of $2.8{ }^{\circ} \mathrm{C}$ (January), and $32.6{ }^{\circ} \mathrm{C}$ (May), respectively. Average annual precipitation is approximately $500 \mathrm{~mm}$, of which $80 \%$ occurs from June through September. A total of 1.7 Mha are devoted to agriculture, and $89 \%$ of this area is under rainfed conditions.

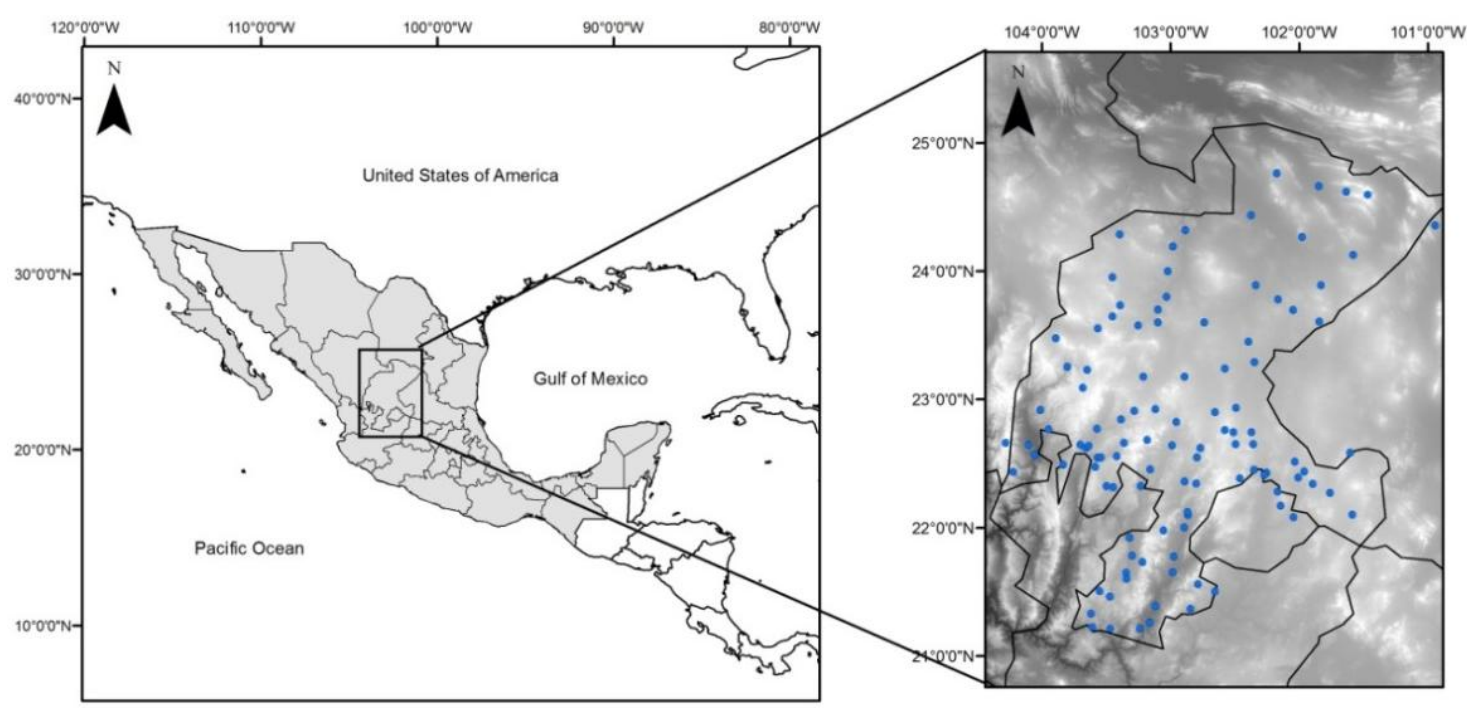

Figure 1. Geographical location of Zacatecas, Mexico. Blue dots represent weather stations

\section{Agroclimatic classification}

The methodology proposed by Papadakis (1980) was used to analyze agroclimatic conditions in Zacatecas. This technique introduces the monthly climate concept to define the climate in a particular place as the sequence of 12 monthly expressions (Velasco and Pimentel, 2010). The monthly climate classification of Papadakis (1980) includes knowledge of monthly thermal and monthly water characteristics within the region under study. According to Campos-Aranda (2005), monthly thermal assessment requires obtaining average maximum temperature $(\mathrm{T})$, average minimum temperature 
$(t)$, and average extreme minimum temperature ( $\left.t^{\prime}\right)$ of a weather dataset. Such values are expressed in Celsius degrees and their combinations result in 31 different thermal climates (Table 1). Monthly water climate is achieved through monthly precipitation (P) and monthly potential evapotranspiration $\left(\mathrm{ET}_{0}\right)$ as well as the amount of water previously stored in the soil (Pant). The comparison between $\mathrm{P}$ plus Pant and $\mathrm{ET}_{0}$ originated 7 different water climates (Table 2).

Table 1. Monthly thermal climates for Papadakis classification Campos-Aranda (2005)

\begin{tabular}{|c|c|c|c|c|c|c|c|c|c|c|c|c|}
\hline & \multirow{2}{*}{$\begin{array}{c}\text { Climate } \\
\text { identifier }\end{array}$} & \multicolumn{3}{|c|}{ Temperatures $\left({ }^{\circ} \mathrm{C}\right)$} & \multirow{2}{*}{$\begin{array}{l}\text { Climate } \\
\text { identifier }\end{array}$} & \multicolumn{3}{|c|}{ Temperatures $\left({ }^{\circ} \mathrm{C}\right)$} & \multirow{2}{*}{$\begin{array}{c}\text { Climate } \\
\text { identifier }\end{array}$} & \multicolumn{3}{|c|}{ Temperatures $\left({ }^{\circ} \mathrm{C}\right)$} \\
\hline & & $\mathbf{t}^{\prime}$ & $\mathbf{T}$ & $\mathbf{t}$ & & $\mathbf{t}^{\prime}$ & $\mathbf{T}$ & $\mathbf{t}$ & & $t^{\prime}$ & $\mathbf{T}$ & $\mathbf{t}$ \\
\hline \multirow{13}{*}{ 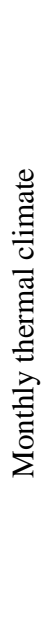 } & A & $<-29$ & $<-17.8$ & & \multirow{2}{*}{ K } & \multirow{2}{*}{0 to 2} & 15 to 21 & \multirow{3}{*}{$<8$} & $S$ & $>7$ & 21 to 25 & 13 to 20 \\
\hline & $\mathrm{B}$ & $<-29$ & $>-17.8$ & & & & $>21$ & & $\mathrm{~T}$ & $>7$ & 25 to 29 & $<13$ \\
\hline & $\mathrm{C}$ & -29 to -10 & $<0$ & & \multirow{2}{*}{$\mathrm{L}$} & \multirow{2}{*}{2 to 7} & 15 to 21 & & $\mathrm{U}$ & $>7$ & 25 to 29 & 13 to 20 \\
\hline & $\mathrm{D}$ & -29 to -10 & 0 to 5 & & & & $>21$ & $<8$ & V & $>7$ & 29 to 33.5 & $<20$ \\
\hline & $\mathrm{e}$ & -29 to -10 & $>5$ & & $\mathrm{~m}$ & -2.5 to 0 & 21 to 25 & $>8$ & $\mathrm{~W}$ & $>7$ & $>33.5$ & $<20$ \\
\hline & E & -10 to -2.5 & 5 to 10 & & $\mathrm{n}$ & 0 to 2 & 21 to 25 & $>8$ & $\mathrm{X}$ & $>7$ & $<29$ & $>20$ \\
\hline & $\mathrm{f}$ & -10 to -2.5 & 10 to 15 & & o & 2 to 7 & 21 to 25 & & $\mathrm{Y}$ & $>7$ & 29 to 33.5 & $>20$ \\
\hline & $\mathrm{F}$ & -10 to -2.5 & $>15$ & & M & -2.5 to 0 & $>25$ & & $\mathrm{Z}$ & $>7$ & $>33.5$ & $>20$ \\
\hline & G & -2.5 to 0 & 10 to 15 & & $\mathrm{~N}$ & 0 to 2 & $>25$ & & & & & \\
\hline & $\mathrm{H}$ & 0 to 2 & 10 to 15 & & $\mathrm{O}$ & 2 to 7 & $>25$ & & & & & \\
\hline & I & 2 to 7 & 10 to 15 & & $\mathrm{P}$ & $>7$ & $<17$ & & & & & \\
\hline & $\mathbf{I}$ & 05 & 15 to 21 & & Q & $>7$ & 17 to 21 & & & & & \\
\hline & J & -2.5 to 0 & $>21$ & $<8$ & $\mathrm{R}$ & $>7$ & 21 to 25 & $<13$ & & & & \\
\hline
\end{tabular}

Table 2. Monthly water climates for Papadakis classification. Adapted from Campos-Aranda (2005)

\begin{tabular}{|c|c|c|c|c|}
\hline & $\begin{array}{c}\text { Climate } \\
\text { identifier }\end{array}$ & Description & Characteristics & Water exceeding \\
\hline \multirow{7}{*}{ 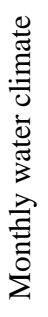 } & $\mathrm{a}$ & Arid & $\mathrm{P}+\mathrm{P}_{\mathrm{ant}}<0.25 \mathrm{ET}_{0}$ & \\
\hline & $\mathrm{s}$ & Dry & $0.25 \mathrm{ET}_{0}<\mathrm{P}+\mathrm{P}_{\mathrm{ant}}<0.50 \mathrm{ET}_{0}$ & \\
\hline & $\mathrm{i}$ & Half-dry & $0.50 \mathrm{ET}_{0}<\mathrm{P}+\mathrm{P}_{\mathrm{ant}}<0.75 \mathrm{ET}_{0}$ & \\
\hline & $\mathrm{y}$ & Half-moist & $0.75 \mathrm{ET}_{0}<\mathrm{P}+\mathrm{P}_{\mathrm{ant}}<\mathrm{ET}_{0}$ & \\
\hline & $\mathrm{p}$ & Pre-moist & $\mathrm{P}+\mathrm{P}_{\mathrm{ant}}>\mathrm{ET}_{0}$ & \\
\hline & $\mathrm{h}$ & Moist & $\mathrm{P}>\mathrm{ET}_{0} ; \mathrm{P}+\mathrm{P}_{\mathrm{ant}}<2 \mathrm{ET}_{0}$ & $<100$ \\
\hline & $\mathrm{w}$ & Wet & $\mathrm{P}>\mathrm{ET}_{0} ; \mathrm{P}+\mathrm{P}_{\mathrm{ant}}>2 \mathrm{ET}_{0}$ & $>100$ \\
\hline
\end{tabular}

An annual climate of the region is defined as the compendium of 12 monthly climates and the elemental components of temperature and humidity, summarizing the most frequent atmospheric behavior which is consistent with other systems of classification. However, the Papadakis (1980) methodology is targeted at the influence of climate factors during crop development (Velasco and Pimentel, 2010). Annual climate is integrated by thermal and water conditions. Thermal expression is defined as function of t' (freezing period) and a thermal number ranged between 0 (cooler month) and 9 (warmer month). On the other hand, water expression evaluates the difference between seasonal rainwater and potential evapotranspiration (exceeding seasonal rainwater) as well as the non-dry months (water number) ranging between 1 to 12 . 


\section{Climatic assessment}

A network composed of 133 weather stations located within the study area was used to measure daily rainfall, and daily minimum, minimum extreme, maximum, and average air temperatures. The weather stations are monitored by the National Water Commission (CONAGUA) of the Mexican Government. The dataset is composed of information collected during the period of 1960-2015. For every weather station, data were filtered and chronologically sorted to complete missing information using a geostatistical and Kalman filter (KF) approach. To estimate potential evapotranspiration, the Hargreaves method was used due to its simplicity, reliability, minimum data requirements, ease of computation, and low impact by weather station aridity (Hargreaves and Allen, 2003; Allen et al., 1998). Equation 1 summarizes such methodology.

$$
\mathrm{ET}_{0}=0.0023 \mathrm{R}_{\mathrm{a}}(\mathrm{T}-\mathrm{t})^{0.5}\left(\frac{\mathrm{T}-\mathrm{t}}{2}+17.8\right)
$$

where $\mathrm{ET}_{0}$ is reference evapotranspiration $\left[\mathrm{mm} \cdot\right.$ day $\left.^{-1}\right]$; $\mathrm{Ra}$ is extraterrestrial radiation $\left[\mathrm{MJ} \mathrm{m}{ }^{-2}\right.$ day $\left.^{-1}\right] ; \mathrm{T}$ is average maximum temperature $\left[{ }^{\circ} \mathrm{C}\right] ; \mathrm{t}$ is average minimum temperature $\left[{ }^{\circ} \mathrm{C}\right]$.

The KF is a set of mathematical equations that provide a best linear unbiased estimate (BLUE) for the state of a system containing noisy data. It also establishes a way to update these estimates when a new measurement becomes available without a need to refer to old data (Junez-Ferreira and Herrera, 2013). The KF relies upon two equations, a dynamic equation and a measurement equation. The KF that is applied using only the measurement equation is called the static Kalman filter, which calculates estimates of a given variable sequentially, starting from a prior estimate and adding new data at each step (Herrera and Pinder, 2005). The static KF was used to estimate climatic missing values of daily rainfall, daily minimum, minimum extreme, maximum, and average air temperature in the study area. Before predicting missing values, exploratory data analysis and structural analysis were realized (Diaz, 2002; Gallardo, 2006; Mendoza-Cázares and Herrera-Zamarrón, 2010; Ávila et al., 2016). The predictions of values at the unsampled sites were undertaken by using a univariate technique. The parameters of the variograms resulting from the geostatistical analyses were used to generate the a priori covariance matrices for the univariate estimates using the Kalman filter. The GSLIB and Minitab software have been used as predictive tools. The measurement equation (Eq. 2) for the application of the Kalman filter is

$$
z_{\mathrm{j}}=H_{j} C+v_{j}
$$

where $H_{j}$ is the $j$ th sampling matrix. The sampling matrix is a $1 x N$ matrix that is nonzero only at the position corresponding to the entry of $C$ where the $j$ th sample is taken, and $N$ is the dimension of the vector $C$. The set $\left\{v_{j}, j=1,2, \ldots\right\}$ represents the measurement error. It is a white Gaussian sequence, with zero mean and variance $r_{j}$. The measurement error sequence $\left\{v_{j}\right\}$ and the vector $C$ are independent. $C=\left\{C_{i p}\right\}$ is the space-time vector, with the climatic values in the positions $\left(x_{i}\right)$ and times $\left(t_{p}\right) ; z_{j}$ is the measurement vector. 


\section{Software for data analysis and agroclimatic mapping}

The database was assembled by using all the collected and processed data in a Microsoft ${ }^{\circledR}$ Excel 2016 spreadsheet. Daily rainfall, daily minimum, minimum extreme, maximum, and average air temperature data underwent quality checking to identify spurious values, and the daily values were transformed into monthly average series. Monthly average values were interpolated using the ordinary Kriging method that embraces a set of methods for local estimation, including simple and ordinary kriging, co-kriging, universal kriging and disjunctive kriging. Ordinary kriging was used in this research. The kriging weights were determined using the variogram and the configuration of the data. It is an optimal interpolator in the sense that estimates are unbiased and have known minimum variances (Oliver and Webster, 1990). Several investigations recommend the use of kriging as interpolator for hydrological variables (O'Conell and Todini, 1996; Holdaway, 1996; Borga and Vizzaccaro, 1997; Bargaoui and Chebbi, 2009). Kriging is a standard method of optimal interpolation included in ArcMap for ArcGIS®.

\section{Results and discussion}

Mean annual values of precipitation and temperature for the period of 1960 to 2015 are shown in Figure 2.

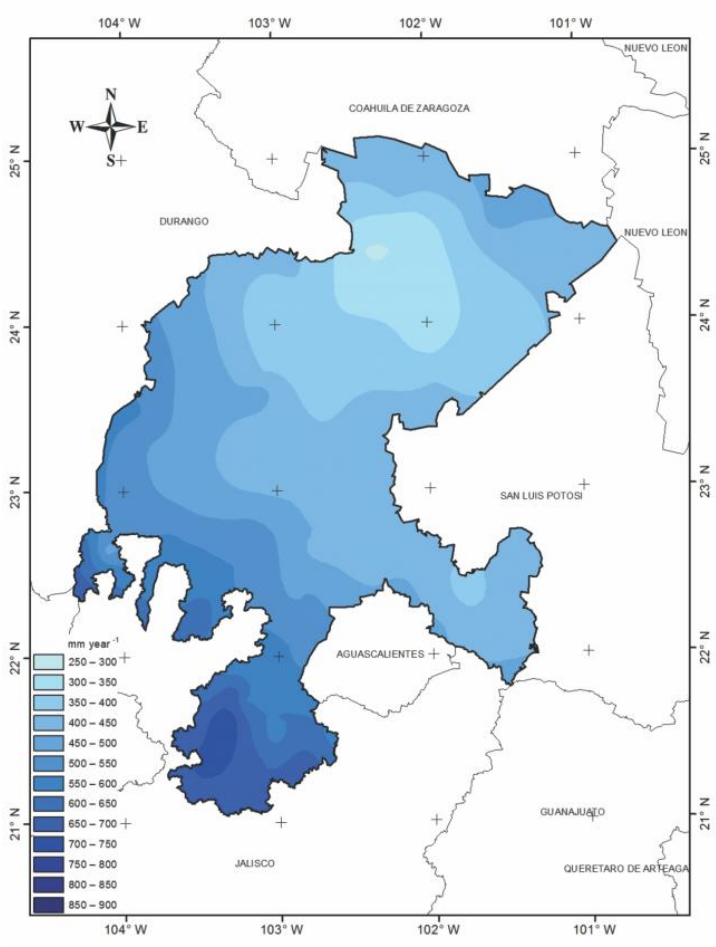

(a)

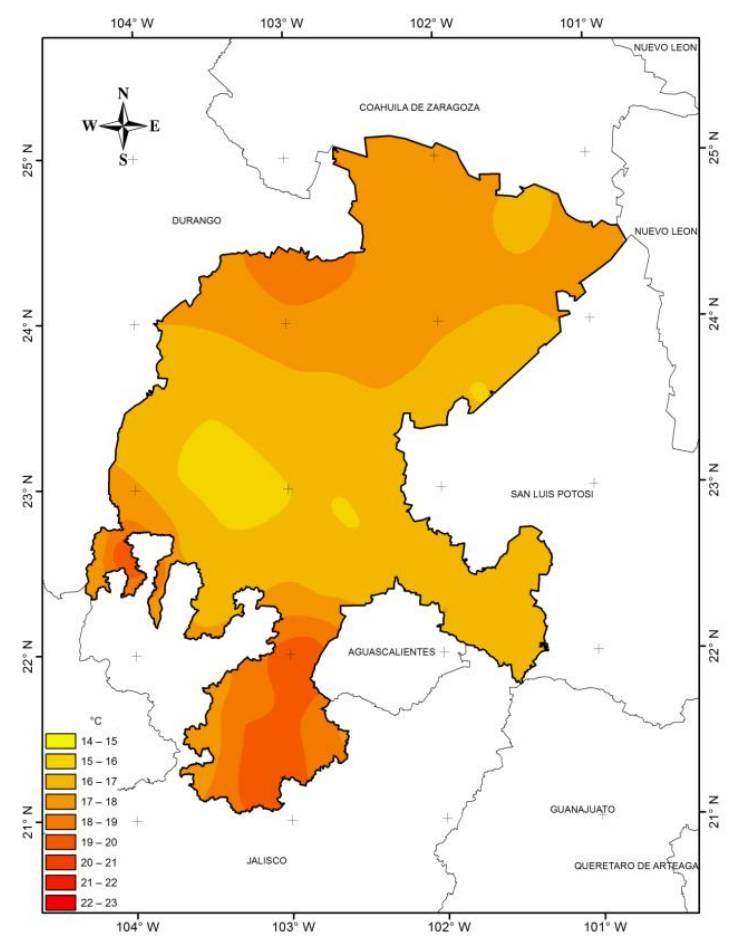

(b)

Figure 2. Mean annual values of precipitation (a) and temperature (b) for the period of 1960 to 2015 of Zacatecas, Mexico

For the period under study, the spatial distribution of the mean precipitation ranges between less than $300 \mathrm{~mm}_{\text {year }}{ }^{-1}$ in the northeast region and $750 \mathrm{~mm}_{\text {year }}{ }^{-1}$ in the south region of Zacatecas state. Notwithstanding, critical years due to both scarcity and excess 
pluvial precipitation were recorded during analysis of the time series. The recent cases occurred in 2011 and 2013 with precipitation rates of $286 \mathrm{~mm}_{\text {year }}{ }^{-1}$ and $678 \mathrm{~mm} \mathrm{year}^{-1}$, respectively. Regarding temperature variations throughout the year, minimum and maximum annual averages were around $14{ }^{\circ} \mathrm{C}$ and $23{ }^{\circ} \mathrm{C}$; nevertheless, minimum mean temperature of $2.8^{\circ} \mathrm{C}$ and maximum mean temperature of $32.6^{\circ} \mathrm{C}$ were reached in January and May, respectively.

Monthly thermal and monthly water climates from January to December for the Zacatecas region following the Papadakis (1980) methodology are plotted in Figure 3.
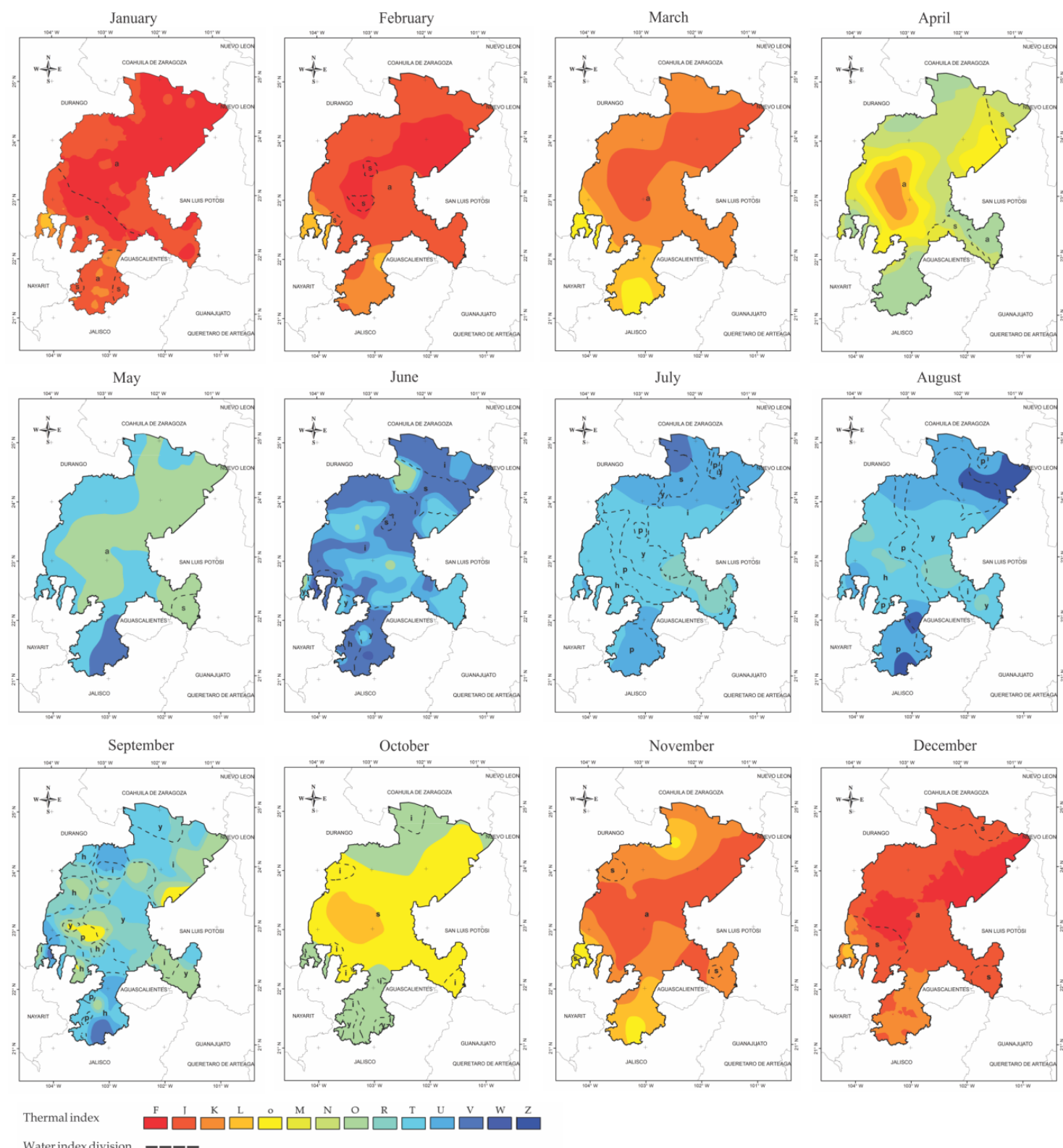

Figure 3. Thermal and water indexes from January to December for Zacatecas, Mexico

Maps show that January, February, November, and December are months that are too cool (more than $85 \%$ of the area is under $\mathrm{F}$ or $\mathrm{J}$ thermal indexes) to cultivate citrus but grass (Festuca) grows with respect to water availability. Actually, orange and lemon 
trees are a way of undertaking subsistence farming in a small portion of the South of the region where the thermal index is between $\mathrm{J}$ and $\mathrm{K}$ in January, the cooler month of year. Coupled with unfavorable thermal indexes for agricultural activities, these months do not reach enough rainfall to satisfy crop water requirements (water indexes between a and $\mathrm{s}$ in the whole region); nevertheless, the Zacatecas region is provided with groundwater resources that make it possible to establish perennial crops such as alfalfa (Medicago sativa L.) and grass (Festuca).

Temperature begins to become benevolent for agriculture from the month of April. This month is usually adopted by farmers who irrigate to sow and take advantage of the market (high prices for early producers). Farmers who do not irrigate wait for the best opportunity that precipitation can provide, choosing the sowing date empirically after the first significant rainfall (Bautista-Capetillo et al., 2016). For rainfed crops, the sowing period usually oscillates between April and July, depending on the type of crop established and once precipitation starts (Luna, 2014; Medina et al., 2003). These facts are in agreement the with Papadakis (1980) classification. The thermal (O and R), and water (i, y, and p) monthly indexes for such a period are in optimal climate conditions for crops as maize and beans, two of the main rainfed crops established in Zacatecas. Table 3 shows a description of monthly thermal index and monthly water index is included as well as their influence on growing crops.

Table 3. Description of thermal and water indexes for Zacatecas territory

\begin{tabular}{|c|c|c|c|c|c|}
\hline \multirow{2}{*}{$\begin{array}{c}\text { Thermal } \\
\text { index }\end{array}$} & \multirow[t]{2}{*}{ Water index } & \multirow[t]{2}{*}{ Month } & \multicolumn{2}{|c|}{$\begin{array}{l}\text { Zacatecas } \\
\text { territory }\end{array}$} & \multirow[t]{2}{*}{ Climatic conditions for growing crops } \\
\hline & & & $\left(K^{2} \mathbf{m}^{2}\right)$ & $\%$ & \\
\hline \multirow{6}{*}{$\mathrm{F}$} & & January & 39,750 & 53.00 & \multirow{3}{*}{$\begin{array}{l}\text { Winter too cold and rainfall shortage. Climatic conditions not } \\
\text { suitable for rainfed growing crops }\end{array}$} \\
\hline & $\mathrm{a}$ & February & 9,750 & 13.00 & \\
\hline & & December & 18,750 & 25.00 & \\
\hline & \multirow{3}{*}{$\mathrm{s}$} & January & 9,000 & 12.00 & \multirow{3}{*}{ Winter too cold. Rainfall remains deficient for rainfed crops } \\
\hline & & February & 6,000 & 8.00 & \\
\hline & & December & 1,500 & 2.00 & \\
\hline \multirow{9}{*}{$\mathrm{J}$} & \multirow{6}{*}{$\mathrm{a}$} & January & 13,500 & 18.00 & \multirow{6}{*}{$\begin{array}{l}\text { Frosts are common and rainfall shortage. Winter cereals grow } \\
\text { because of vernalization but they need irrigation water }\end{array}$} \\
\hline & & February & 46,500 & 62.00 & \\
\hline & & March & 27,750 & 37.00 & \\
\hline & & April & 9,000 & 12.00 & \\
\hline & & November & 32,250 & 43.00 & \\
\hline & & December & 36,000 & 48.00 & \\
\hline & \multirow{3}{*}{$\mathrm{s}$} & January & 5,250 & 7.00 & \multirow{3}{*}{$\begin{array}{c}\text { Frosts are common. Rainfall remains deficient for rainfed crops } \\
\text { but winter cereals grow under irrigation }\end{array}$} \\
\hline & & February & 2,250 & 3.00 & \\
\hline & & December & 9,750 & 13.00 & \\
\hline \multirow{9}{*}{ K } & \multirow{6}{*}{$\mathrm{a}$} & January & 3,750 & 5.00 & \multirow{6}{*}{$\begin{array}{c}\text { Minimum risk of frost and rainfall shortage. Corn, alfalfa, grass, } \\
\text { and cryophilic trees grow under irrigation }\end{array}$} \\
\hline & & February & 6,750 & 9.00 & \\
\hline & & March & 31,500 & 42.00 & \\
\hline & & April & 8,250 & 11.00 & \\
\hline & & November & 24,000 & 32.00 & \\
\hline & & December & 5,250 & 7.00 & \\
\hline & \multirow{3}{*}{$\mathrm{s}$} & January & 2,250 & 3.00 & \multirow{3}{*}{$\begin{array}{l}\text { Minimum risk of frost. Rainfall remains deficient for rainfed } \\
\text { crops but corn, alfalfa, grass, and cryophilic trees grow under } \\
\text { irrigation }\end{array}$} \\
\hline & & February & 750 & 1.00 & \\
\hline & & November & 3,750 & 5.00 & \\
\hline
\end{tabular}




\begin{tabular}{|c|c|c|c|c|c|}
\hline & & December & 3,750 & 5.00 & \\
\hline \multirow{7}{*}{$\mathrm{L}$} & \multirow{4}{*}{ a } & February & 3,000 & 4.00 & \multirow{4}{*}{$\begin{array}{l}\text { Frosts are too rare but cold is appropriate for some cryophilic } \\
\text { trees. Corn, beans, cereals, alfalfa, and grass need irrigation } \\
\text { water for optimal growth }\end{array}$} \\
\hline & & March & 10,500 & 14.00 & \\
\hline & & April & 7,500 & 10.00 & \\
\hline & & November & 7,500 & 10.00 & \\
\hline & \multirow{3}{*}{$\mathrm{s}$} & January & 1,500 & 2.00 & \multirow{3}{*}{$\begin{array}{l}\text { Frosts are too rare but cold is appropriate for some cryophilic } \\
\text { trees. Even though rainfall is not enough, corn, beans, cereals, } \\
\text { alfalfa, and grass grow under irrigation }\end{array}$} \\
\hline & & October & 12,000 & 16.00 & \\
\hline & & November & 3,000 & 4.00 & \\
\hline \multirow{10}{*}{ o } & \multirow{3}{*}{$\mathrm{a}$} & March & 5,250 & 7.00 & \multirow{3}{*}{$\begin{array}{l}\text { No frosts and cold is not appropriate for vernalization. Rainfall } \\
\text { shortage, then legumes and vegetables need irrigation water for } \\
\text { growth }\end{array}$} \\
\hline & & April & 10,500 & 14.00 & \\
\hline & & November & 3,750 & 5.00 & \\
\hline & \multirow{3}{*}{$\mathrm{s}$} & April & 1,500 & 2.00 & \multirow{3}{*}{$\begin{array}{l}\text { No frosts and cold is not appropriate for vernalization. Rainfed } \\
\text { beans grow with considerable risk }\end{array}$} \\
\hline & & October & 28,500 & 38.00 & \\
\hline & & November & 750 & 1.00 & \\
\hline & \multirow{2}{*}{$\mathrm{i}$} & September & 2,250 & 3.00 & \multirow{4}{*}{$\begin{array}{l}\text { No frosts and cold is not appropriate for vernalization. Bean crop } \\
\text { and corn crop grow under rainfed conditions }\end{array}$} \\
\hline & & October & 6,000 & 8.00 & \\
\hline & $\mathrm{y}$ & September & 750 & 1.00 & \\
\hline & $\mathrm{p}$ & September & 2,250 & 3.00 & \\
\hline \multirow{2}{*}{ M } & $\mathrm{a}$ & April & 8,250 & 11.00 & \multirow{9}{*}{$\begin{array}{l}\text { Temperature is adequate for initial season development stage of } \\
\text { legume and vegetables grow but need irrigation water }\end{array}$} \\
\hline & $\mathrm{s}$ & April & 2,250 & 3.00 & \\
\hline \multirow{2}{*}{$\mathrm{N}$} & $\mathrm{a}$ & April & 12,750 & 17.00 & \\
\hline & $\mathrm{s}$ & April & 3,750 & 5.00 & \\
\hline \multirow{8}{*}{$\mathrm{O}$} & $\mathrm{a}$ & April & 9,750 & 13.00 & \\
\hline & a & May & 39,750 & 53.00 & \\
\hline & \multirow{4}{*}{$\mathrm{S}$} & April & 1,500 & 2.00 & \\
\hline & & May & 3,750 & 5.00 & \\
\hline & & June & 4,500 & 6.00 & \\
\hline & & October & 14,250 & 19.00 & $\begin{array}{l}\text { Temperature is adequate for garlic, onion, and carrot grow but } \\
\text { need irrigation water }\end{array}$ \\
\hline & $\mathrm{i}$ & October & 8,250 & 11.00 & Temperature is adequate for garlic, onion, and carrot grow but \\
\hline & $\mathrm{y}$ & October & 6,000 & 8.00 & rainfall has to be complemented using irrigation water \\
\hline \multirow{8}{*}{$\mathrm{R}$} & $\mathrm{j}$ & July & 5,250 & 7.00 & \multirow{8}{*}{$\begin{array}{c}\text { Temperature and rainfall are quite adequate for bean crop and } \\
\text { corn crop at midseason development stage. Vegetables as pepper } \\
\text { grow using irrigation water }\end{array}$} \\
\hline & 1 & September & 4,500 & 6.00 & \\
\hline & & July & 750 & 1.00 & \\
\hline & $\mathrm{y}$ & August & 5,250 & 7.00 & \\
\hline & & September & 6,750 & 9.00 & \\
\hline & $\mathrm{p}$ & September & 3,750 & 5.00 & \\
\hline & \multirow{2}{*}{$\mathrm{h}$} & August & 4,500 & 6.00 & \\
\hline & & September & 6,000 & 8.00 & \\
\hline \multirow{6}{*}{$\mathrm{T}$} & $\mathrm{a}$ & May & 26,250 & 35.00 & Temperature is adequate for initial season development stage of \\
\hline & $\mathrm{s}$ & June & 3,750 & 5.00 & legume and vegetables grow but need irrigation water \\
\hline & & June & 10,500 & 14.00 & Temperature and rainfall are quite adequate for bean crop and \\
\hline & $\mathrm{i}$ & July & 11,250 & 15.00 & corn crop at midseason development stage as well as for \\
\hline & 1 & September & 6,750 & 9.00 & Mexican wheat crop. Vegetables as pepper grow using irrigation \\
\hline & & August & 3,750 & 5.00 & water \\
\hline & & June & 3,000 & 4.00 & Temperature and rainfall are quite adequate for bean crop and \\
\hline $\mathrm{T}$ & & July & 12,750 & 17.00 & corn crop at midseason development stage as well as for \\
\hline 1 & $\mathrm{y}$ & August & 6,750 & 9.00 & Mexican wheat crop. Vegetables as pepper grow using irrigation \\
\hline & & September & 9,750 & 13.00 & \\
\hline
\end{tabular}




\begin{tabular}{|c|c|c|c|c|c|}
\hline & \multirow{3}{*}{$\mathrm{p}$} & July & 12,000 & 16.00 & \\
\hline & & September & 4,500 & 6.00 & \\
\hline & & August & 6,000 & 8.00 & \\
\hline & \multirow{3}{*}{$\mathrm{h}$} & July & 7,500 & 10.00 & \\
\hline & & August & 14,250 & 19.00 & \\
\hline & & September & 6,750 & 9.00 & \\
\hline \multirow{16}{*}{$\mathrm{U}$} & \multirow{2}{*}{$\mathrm{s}$} & June & 9,750 & 13.00 & \multirow{2}{*}{$\begin{array}{c}\text { Temperature is adequate for bean crop but rainfall is not enough } \\
\text { to satisfy crop water requirements }\end{array}$} \\
\hline & & July & 3,750 & 5.00 & \\
\hline & \multirow{4}{*}{$\mathrm{i}$} & June & 9,000 & 12.00 & \multirow{14}{*}{$\begin{array}{l}\text { Temperature and rainfall are quite adequate for bean crop and } \\
\text { corn crop at midseason development stage as well as for } \\
\text { Mexican wheat crop. Vegetables as pepper grow using irrigation } \\
\text { water }\end{array}$} \\
\hline & & July & 11,250 & 15.00 & \\
\hline & & August & 7,500 & 10.00 & \\
\hline & & September & 9,000 & 12.00 & \\
\hline & \multirow{4}{*}{$\mathrm{y}$} & June & 4,500 & 6.00 & \\
\hline & & July & 3,000 & 4.00 & \\
\hline & & August & 5,250 & 7.00 & \\
\hline & & September & 750 & 1.00 & \\
\hline & \multirow{3}{*}{$\mathrm{p}$} & July & 2,250 & 3.00 & \\
\hline & & August & 8,250 & 11.00 & \\
\hline & & September & 2,250 & 3.00 & \\
\hline & & July & 750 & 1.00 & \\
\hline & $\mathrm{h}$ & August & 3,750 & 5.00 & \\
\hline & & September & 4,500 & 6.00 & \\
\hline \multirow{8}{*}{$\mathrm{V}$} & $\mathrm{a}$ & May & 5,250 & 7.00 & \multirow{3}{*}{$\begin{array}{l}\text { High temperatures during day but refreshing nights which harms } \\
\text { some cultivars. Rainfall shortage }\end{array}$} \\
\hline & \multirow{2}{*}{$\mathrm{s}$} & June & 6,750 & 9.00 & \\
\hline & & July & 2,250 & 3.00 & \\
\hline & i & June & 12,000 & 16.00 & \multirow{9}{*}{$\begin{array}{l}\text { High temperatures during day but refreshing nights which harms } \\
\text { some cultivars. Rainfall is suitable for bean crop and corn crop }\end{array}$} \\
\hline & 1 & July & 2,250 & 3.00 & \\
\hline & $\mathrm{y}$ & June & 6,750 & 9.00 & \\
\hline & & June & 3,750 & 5.00 & \\
\hline & $\mathrm{h}$ & September & 4,500 & 6.00 & \\
\hline $\mathrm{W}$ & $\mathrm{y}$ & June & 750 & 1.00 & \\
\hline \multirow{3}{*}{$\mathrm{Z}$} & $\mathrm{y}$ & August & 3,750 & 5.00 & \\
\hline & $\mathrm{i}$ & August & 3,000 & 4.00 & \\
\hline & $\mathrm{h}$ & August & 3,000 & 4.00 & \\
\hline
\end{tabular}

The annual agroclimatic classification (Papadakis, 1980) for the Zacatecas region is mapped in Figure 4. Three different agroclimatic zones were obtained (2.1, Semitropical cold zone; 2.2, Low cold zone; and 2.3, Middle cold zone). More than $90 \%$ of the surface is under the 2.2 climate type favoring crops such as maize, beans, and soybeans but dryland farmers have to wait for the best opportunity that precipitation can provide, choosing the sowing date empirically after the first significant rainfall. The sowing period oscillates between July 1 and August 1. In winter, the temperature permits the growing of wheat but since this season of the year is generally dry, it should be irrigated. The annual water regime varies from semiarid to humid; rainfed crops depend on the availability of rainfall occurring in May or June. About $9 \%$ and $1 \%$ of Zacatecas are under 2.3 and 2.1 climate types, respectively. The same crops as the 2.2 climate type can be established as well as forage crops such as maize, oats, sorghum, grasses and alfalfa. Additionally, rainfed bean crop is sown in spring and summer 
seasons. It should be noted that the classification of Köppen modified by Garcia places the Zacatecas region in a subtropical environment with some days having temperatures below $0{ }^{\circ} \mathrm{C}$. Almost $90 \%$ of the region is mainly covered by semiarid and arid environments affected by droughts of different intensities (Bautista-Capetillo et al., 2016; Mojarro et al., 2013; Medina et al., 1998).

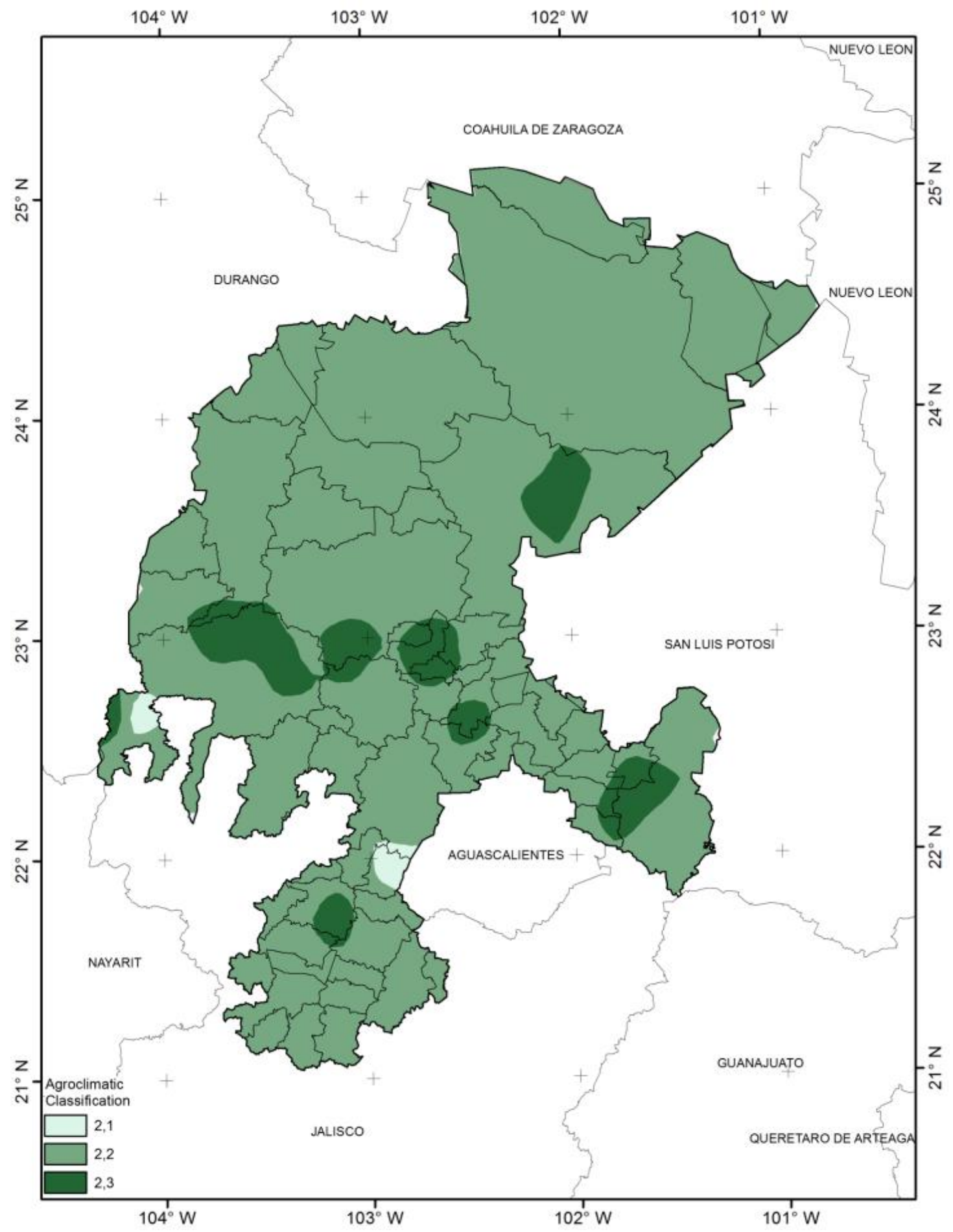

Figure 4. Climatology Papadakis classification zones for Zacatecas, Mexico 
According to the agroclimatic classification of Papadakis (1980), the Zacatecas region is suitable for maize and bean crops. This region of Mexico is the major producer of bean crop in the country (Flores and Bautista-Capetillo, 2015). Around 400,000 ha of bean crop are harvested annually (95\% is dryland and 5\% is irrigated land); meanwhile, maize crop harvests reach 235,000 ha per year $(85 \%$ is dryland and $15 \%$ is irrigated land). The importance for Mexico of beans cultivated in Zacatecas is contextualized as follows: between 20 and 23 Mha are annually farmed in the country (CONAGUA, 2016). Dry beans are established in $12 \%$ of the total agricultural land. Most of this area is rainfed (1.6 Mha), while only $0.3 \mathrm{Mha}$ is irrigated. The current average yields are $0.53 \mathrm{Mg} \mathrm{ha}^{-1}$ and $1.53 \mathrm{Mg} \mathrm{ha}^{-1}$ for rainfed and irrigation conditions, respectively (SIAP, 2013). Factors such as crop genetics, soil physics, fertilizer use, and water stress affect crop production. Dry beans are grown all over the country during the Spring-Summer season but the main producers are the states of Zacatecas, Durango, and San Luis Potosi with 0.75 Mha cultivated. In the Fall-Winter season only 0.27 Mha are cultivated, the main producers are the states of Chiapas, Nayarit, Veracruz and Sinaloa.

Maize and bean crop yield in rainfed agriculture generates low incomes for farmers because economic productivity of these products is barely $200 \mathrm{USD} \mathrm{Mg}^{-1}$ and $150 \mathrm{USD}$ $\mathrm{Mg}^{-1}$, respectively. These conditions entail socio-economical aspects that should be considered. The agroclimatic context of the Zacatecas region is useful for such crops but the economic profit margin is lower than farmer expectations. For this reason, agricultural producers have taken advantage of natural resources such as soil and groundwater which allow them to cultivate vegetables (chilli, pepper, garlic, onion, tomato, carrot, lettuce) and perennial crops that are mainly alfalfa and grass. In fact, chilli (both fresh and dry) produced in the Zacatecas region places this region as the second producer in the Mexican market; the value of production is around 3,400.00 $\mathrm{USD} \mathrm{Mg}^{-1}$ (SAGARPA, 2017) yielding 1.1 MMg per year approximately. Nevertheless, some environmental effects occur in Zacatecas aquifers because of high water extractions. CONAGUA (2016) estimates that $1,397.3 \mathrm{Hm}^{3}$ of groundwater is used annually for agriculture in Zacatecas. As a consequence of the intensive exploitation of aquifers, undesirable effects have been documented in the body of scientific literature, such as: the accelerated extraction rates of water tables (Carrillo-Rivera et al., 2008; Maderey-Rascón and Carrillo-Rivera, 2005), the degradation of water quality in wells (Kresic, 2007; Freeze and Cherry, 1979), subsidence (Fetter, 1994; Bear, 1979), as well as alterations to ecosystems (Carabias et al., 2005).

\section{Conclusions}

Mexico frequently faces adverse climatic conditions. In southeastern Mexico, the country has undergone large floods, while central and northern Mexico experienced critical droughts. Agroclimatic understanding is particularly important in semiarid regions because this permits proactive action in promoting the agricultural potential of regions with scarce rainfall regimes. Bautista-Capetillo et al. (2016) note that $73 \%$ of the Zacatecas region $\left(75,284 \mathrm{~km}^{2}\right.$ ) is characterized by dry climate (rainfall is lower than potential evapotranspiration) with significant limitations for agriculture (INEGI, 2016). The agroclimatic maps presented in the present paper confirm such asseverations. The climate variables analyzed for the period of 1960-2015 show that large areas of Zacatecas are not dedicated to rainfed agriculture during months of January, February, November, and December but such a condition starts to change from April. In that 
month, the average temperature increases by up to $24{ }^{\circ} \mathrm{C}$; nevertheless, precipitation still is not enough to satisfy crop water requirements of a low consumption of this resource. According to Papadakis (1980) agroclimatic classification, at least 90\% of Zacatecas is adequate to establish maize and bean crops under rainfed conditions but these types of crops generate low incomes for farmers. For this reason, they opted for vegetables and taking advantage of natural resources such as soil and groundwater with environment consequences such as depletion of aquifers. The agroclimatic analysis carried out for Zacatecas state can be useful to design policies concerning the preservation of natural resources, such as water. Because of this, our contribution could support the management of regional rainfed agriculture, providing fresh information about incidence of temperature and rainfall conditions for Zacatecas territory through maps that show thermal and water indexes of the Papadakis agroclimatology classification.

Acknowledgments. The authors express their gratitude to the Universidad Autónoma de Zacatecas of Mexico, for the support provided to carry out the agroclimatic project in Zacatecas territory. The authors also express their gratitude to the Mexican National Council for Science and Technology (CONACYT) for financing the scholarship of one of the authors, namely, Pacheco-Guerrero Anuard.

\section{REFERENCES}

[1] Allen, R. G., Pereira, L. S., Raes, D., Smith, M. (1998): Crop Evapotranspiration: Guidelines for Computing Crop Water Requirements; Paper 56. - Food and Agriculture Oreganization of the United Nations, Rome, Italy.

[2] Ávila-Carrasco, J. R., Júnez-Ferreira, H. E., González-Trinidad, J., Villalobos de Alba, A. A., Bautista-Capetillo, C. F. (2016): Comparison of univariate approaches to map precipitation using geostatistics and the Kalman filter. - Applied Ecology and Environmnetal Research 14(3): 735-751. doi: 10.15666/aeer/1403_735751.

[3] Bargaoui, Z. K., Chebbi, A. (2009): Comparison of two kriging interpolation methods applied to spatiotemporal rainfall. - Journal of Hydrology 365: 56-73. doi: 10.1016/j.jhydrol.2008.11.025.

[4] Bautista-Capetillo, C., Carrillo, B., Picazo, G., Junez-Ferreira, H. (2016): Drought assessment in Zacatecas, Mexico. - Water 8(10): 1-15. doi: 10.3390/w8100416.

[5] Bear, J. (1979) Hydraulics of Groundwater. - McGraw-Hill, NY, USA.

[6] Borga, M., Vizzacaro, A. (1997): On the interpolation of hydrologic variables: a formal equivalence of multiquadratic surface fitting and kriging. - Journal of Hydrology 195: 160-171. doi: 10.1016/S0022-1694(96)03250-7.

[7] Campos-Aranda, D. F. (1999): Clasificación agroclimática de Papadakis: normas y procedimientos de aplicación. - Universidad Autónoma de San Luis Potosí, San Luis Potosí, Mexico.

[8] Campos-Aranda, D. F. (2005): Agroclimatología cuantitativa de cultivos. - Editorial Trillas SA de CV, México D. F.

[9] Carabias, J., Landa, R., Collado, J., Martínez, P. (2005): Agua, medio ambiente y sociedad. Hacia la gestión integral de los recursos hídricos en México. - Universidad Nacional Autónoma de México, El Colegio de México A. C., Fundación Gonzalo Río Arronte, I. A. P., México D. F., México.

[10] Carrillo Rivera, J. J., Cardona A, Huizar-Alvarez, R., Graniel, E. (2008): Response of the interaction between groundwater and other components of the environment in Mexico. Environmental Geology 55(2): 303-319. doi: 10.1007/s00254-007-1005-2. 
[11] CONAGUA (2016): Estadísticas del agua en México. Secretaría de Medio Ambiente y Recursos Naturales. - Comisión Nacional del Agua, Goverment of Mexico, México D. F., Mexico.

[12] Di Castri, F., Hajek, E. R. (1976): Bioclimatología de Chile; Vicerrectoría Académica de la Universidad Católica de Chile. - Santiago, Chile.

[13] Díaz, B. M., Plascencia, H., Arteaga, R., Vázquez, M. A. (2000): Estudio y zonificación agroclimáticos en la región Los Altos de Chiapas, México. - Investigaciones Geográficas 42: 7-27.

[14] Díaz, M. A. (2002): Geoestadística aplicada, Instituto de Geofísica, Universidad Nacional Autónoma de México. - Instituto de Geofísica y Astronomía, CITMA, Cuba; México D. F., Mexico.

[15] Falasca, S. L., Ulberich, A. C., Ulberich, E. (2012): Developing an agro-climatic zoning model to determine potential production areas for castor bean (Ricinus communis L.). Industrial Crops and Products 40: 185-191. doi: 10.1016/j.indcrop.2012.02.044.

[16] Fetter, C. W. (1994): Applied Hydrogeology, 3rd ed. - Prentice-Hall, NJ, USA.

[17] Flores, L. I., Bautista-Capetillo, C. (2015): Green and blue water footprint accounting for dry beans (Phaseolus vulgaris) in primary region of Mexico. - Sustainability 7: 30013016. doi: 10.3390/su7033001.

[18] Freeze, R. A., Cherry, J. A. (1979): Groundwater. - Prentice-Hall Inc., Englewood Cliffs, NJ, USA.

[19] Gallardo, A. (2006): Geostadística. - Revista Ecosistemas 15(3): 2.

[20] García, E. (2004): Modificaciones al sistema de clasificación climático de Köppen, 5th ed. - Instituto de Geografía, Universidad Nacional Autónoma de México (UNAM), México D. F., Mexico, ISBN 970-32-1010-4.

[21] García, M., Raes, D., Jacobsen, S. E., Michel, T. (2007): Agroclimatic constraints for rainfed agriculture in the Bolivian Altiplano. - Journal of Arid Environments 71(1): 109121. doi: 10.1016/j.jaridenv.2007.02.005.

[22] Geerts, S., Raes, D., Garcia, M., Del Castillo, C., Buytaert, W. (2006): Agro-climatic suitability mapping for crop production in the Bolivian Altiplano: A case study for quinoa. - Agricultural and Forest Meteorology 139(3): 399-412. doi: 10.1016/j.agrformet.2006.08.018.

[23] Hargreaves, G. H., Allen, R. G. (2003): History and evaluation of Hargreaves evapotranspiration equation. - Journal of Irrigation and Drainage Engineering 129(1): 5363. doi: 10.1061/(ASCE)0733-9437(2003)129: 1(53).

[24] Herrera, G. S., Pinder, G. F. (2005): Space-time optimization of groundwater quality sampling networks. - Water Resources Research 41: W12407. doi: 10.1029/2004WR003626.

[25] Holdaway, M. R. (1996): Spatial modeling and interpolation of monthly temperature using kriging. - Climate Research 6: 215-225. doi: 10.3354/cr006215.

[26] Holden, N. M., Brereton, A. J. (2004): Definition of agroclimatic regions in Ireland using hydro-thermal and crop yield data. - Agricultural Forest Meteorology 122: 175-191. doi: 10.1016/j.agrformet.2003.09.010.

[27] Instituto Nacional de Estadística y Geoegrafía INEGI (2017):Información del Territorio Nacional por Entidad. Government of Mexico. http://cuentame.inegi.org.mx/monografias/informacion/zac/ ispepi. (accessed on 4 May 2017).

[28] Júnez-Ferreira, H. E., Herrera, G. S. (2013): A geostatistical methodology for the optimal design of space-time hydraulic head monitoring networks and its application to the Valle de Queretaro aquifer. - Environmental Monitoring Assessment 185: 3527-3549. doi: 10.1007/s10661-012-2808-5.

[29] Köppen, W. (1936): Das geographische system der climate. - In: Köppen, W., Geiger, R. (eds.) Handbuch der Klimatologie, Volume I, Part C. Borntraeger Science Publishers, Berlin, Germany. 
[30] Kresic, N. (2007): Hydrogeology and groundwater modeling, 2nd ed. - Taylor and Francis Group, Boca Raton, FL, USA.

[31] Luna, M. (2014): Antología Cultivos Básicos en Zacatecas. - Universidad Autónoma de Zacatecas, Zacatecas, Mexico. https://www.academia.edu/11532162/ (accessed on 16 August 2016).

[32] Maderey-Rascón, L. E., Carrillo-Rivera, J. J. (2005): El Recurso Agua en México: Un análisis geográfico. - Instituto de Geografía, UNAM, México D. F., Mexico.

[33] Martinez, J., Martinez, A., Makkar, H., Francis, G., Becker, K. (2010): Agroclimatic conditions, chemical and nutritional characterization of different provenances of Jatropha curcas L. from Mexico. - European Journal of Scientific Research 39(3): 396-407.

[34] Medina, G.; Rumayor, R.; Cabañas, C.; Luna, F.; Ruiz, C.; Gallegos, V.; Madero, J.; Gutiérrez, R.; Rubio, S.; Bravo, L. (2003): Potencial Productivo de Especies Agrícolas en el Estado de Zacatecas. - Instituto Nacional de Investigaciones Forestales, Agrícolas y Pecuarias, Centro de Investigación Regional Norte Centro, Calera, isẹp:Zacatecas, Mexico.

[35] Medina García, G.; Ruiz Corral, J. A., Martínez Parra, R. A. (1998): Los climas de México. Una estratificación ambiental basada en el componente climático, Instituto Nacional de Investigaciones Forestales, Agrícolas y Pecuarias; Secretaría de Ganadería y Agricultura; Guadalajara, Jalisco, México; pp. 103.

[36] Mendoza-Cázares, E. Y., Herrera-Zamarrón, G. (2010): Estimación espacio-temporal de la carga hidráulica utilizando el concepto de función aleatoria espacio-tiempo. Tecnología y Ciencias del Agua 1(2): 87-111.

[37] Moeletsi, M. E., Walker, S. (2013): Agroclimatological suitability mapping for dryland maize production in Lesotho. - Theoretical and Applied Climatology 114(1-2): 227-236. doi: 10.1016/j.agrformet.2012.04.009.

[38] Mojarro, F., De Leon, B., Junez, H. E., Bautista-Capetillo, C. (2013): Caracterización de la sequía y el cambio climático. - In: Mojarro, F., Bautista-Capetillo C. (eds.) Agua subterránea en Zacatecas, diagnóstico y gestión sustentante de seis acuíferos. Universidad Autónoma de Zacatecas, Zacatecas, México.

[39] Morales, L., Canessa, F., Mattar, C., Orrego, R., Matus, F. (2006): Caracterización y zonificación edáfica y climática de la Región de Coquimbo, Chile. - Revista de la Ciencia del Suelo y Nutrición Vegetal 6(3): 52-74. doi: 10.4067/S071827912006000300005.

[40] Núñez-Colín, C. A., Goytia-Jiménez, M. A. (2009): Distribution and agroclimatic characterization of potential cultivation regions of physic nut in Mexico. - Pesquisa Agropecuaria Brasileira 44(9): 1078-1085. doi: 10.1590/S0100-204X2009000900002.

[41] O'Connell, P. E., Todini, E. (1996): Modelling of rainfall, flow and mass transport in hydrological systems: an overview. - Journal of Hydrology 175: 3-16. doi: 10.1016/S0022-1694(96)80003-5.

[42] Oliver, M. A., Webster, R. (1990): Kriging: a method of interpolation for geographical information systems. - International Journal of Geographical Information Systems 43: 313-332. doi: 10.1080/02693799008941549.

[43] Papadakis, J. (1980): El clima. Con especial referencia a los climas de América Latina, Península Ibérica, ex-colonias Ibéricas y sus potencialidades agropecuarias. - Editorial Albatros, Buenos Aires, República Argentina.

[44] Secretaria de Agricultura, Ganaderia, Desarrollo Rural y Pesca SAGARPA (2017): http://www.sagarpa.gob.mx/Delegaciones (accessed on 16 may 2017).

[45] Servicio de Información Agroalimentaria y Pesquera SIAP (2015): http://www.siap.gob.mx/agricultura-produccion-anual/ (accessed on 4 October 2015).

[46] Terán, C. C., Jimenez, C., Villaneda, E., Gonzalez, C. (1998): Agroclimatic analysis of the region La Mojana (Colombia). - In: Adaptabilidad de la producción agropecuaria en los ecosistemas de La Mojana, Colombia, Colombia.

[47] Thornthwaite, C. W. (1948): An approach toward a rational classification of climate. Geographical Review 38(1): 55-94. doi: 10.2307/210739. 
[48] Velasco, I., Pimentel, E. (2010): Zonificación agroclimática de Papadakis aplicada al estado de Sinaloa, México. - Investigaciones geográficas 73: 86-102.

[49] Vidal, A. S., Martelo, M. T. (2016):Metodología para zonificación de cultivos. Dirección General de Información Suelos, Agua y Vegetación. http://observatoriogeograficoamericalatina.org.mx/egal4/Teoriaymetodo/Metodologicos/1 6.pdf (accessed on 0308 2016).

[50] White, D. H., Lubulwa, G. A., Menz, K., Zuo, H., Wint, W., Slingenbergh, J. (2001): Agro-climatic classification systems for estimating the global distribution of livestock numbers and commodities. - Environment International 27(2): 181-187. doi: 10.1016/S0160-4120(01)00080-0. 